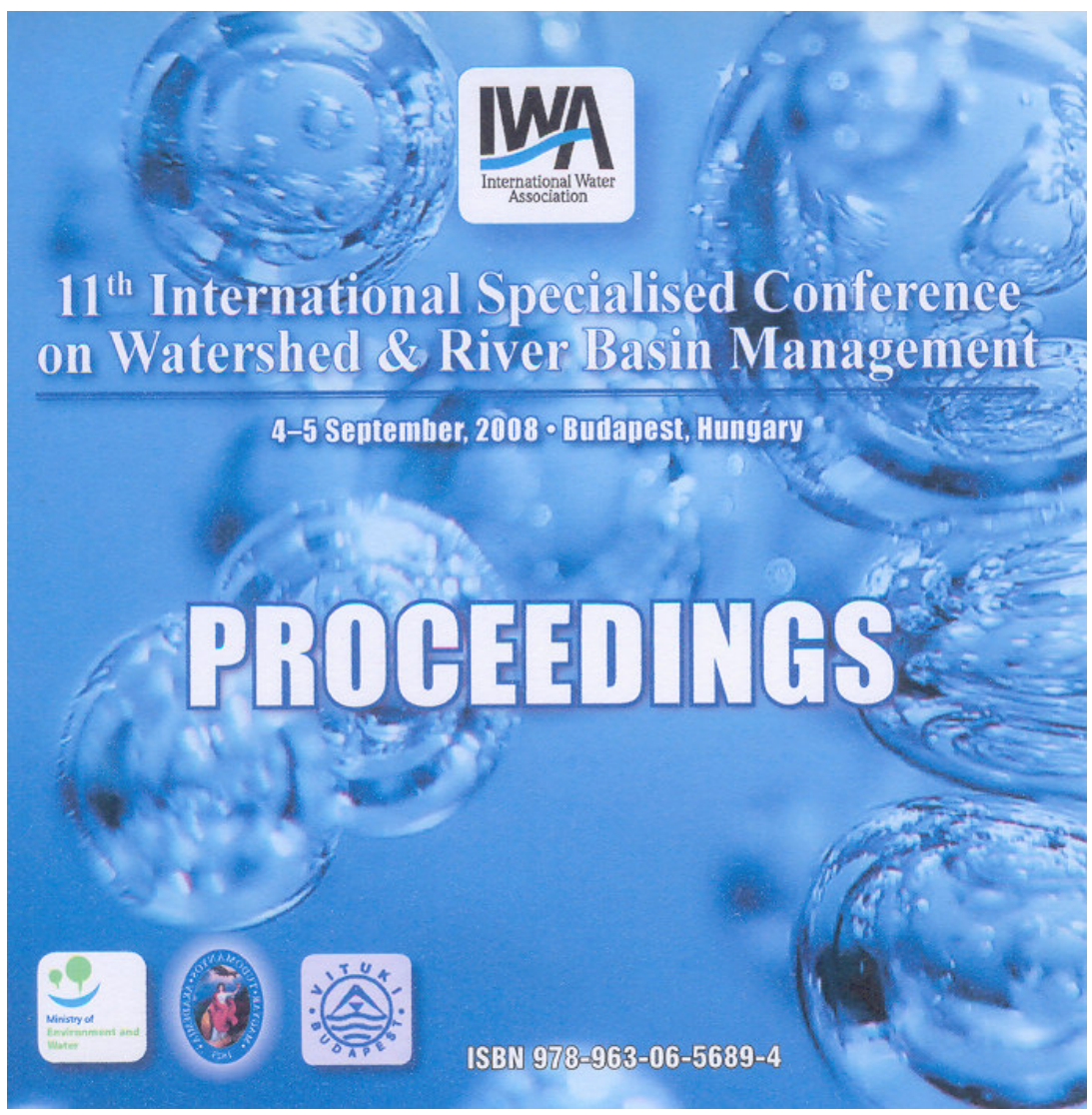

Cikk hivatkozás:

Szilágyi, F., Ács, É., Borics, G., Halasi-Kovács, B., Juhász, P., Kiss, B. Kovács, T., Müller, Z., Lakatos, G., Padisák, J., Pomogyi, P., StengerKovács, C., Szabó, K.É., Szalma, E., Tóthmérész, B. (2008): Application of Water Framework Directive in Hungary: Development of biological classification systems . - In: Zessner, M. (ed.): $11^{\text {th }}$ International Specialized Conference on Watershed and River Basin Management, 4-5 September, 2008, Budapest, ISBN 978-963-06-5689-4 (interactive CD, page numbers are not indicated) 


\title{
Application of Water Framework Directive in Hungary: Development of biological classification systems
}

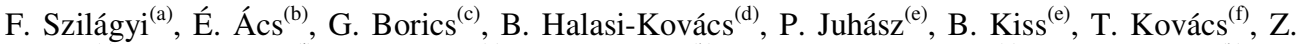 \\ Müller $^{(\mathrm{e})}$, G. Lakatos ${ }^{(\mathrm{j})}$, J. Padisák ${ }^{(\mathrm{g})}$, P. Pomogyi ${ }^{(\mathrm{h})}$, C. Stenger-Kovács ${ }^{(\mathrm{g})}$, K. É. Szabó ${ }^{(\mathrm{b})}$, E. \\ Szalma $^{(\mathrm{i})}$, B. Tóthmérész ${ }^{(\mathrm{j})}$
}

(a) Department of Sanitary and Environmental Engineering, Budapest University of Technology and Economics, Müegyetem rkp. 3, H-1111 Budapest, Hungary, (E-mail: szilagyi@vkkt.bme.hu)

(b) Hungarian Academy of Sciences, Hungarian Danube Research Station, Jávorka S. u. 14, H2131 Göd, Hungary, (E-mail: acs@ludens.elte.hu)

(c) Trans-Tiszaian Environmental, Natural Protection and Water Management Inspectorate, $H$ 4025 Hatvan u. 16, Debrecen, Hungary, (E-mail: boricsg@gmail.com)

(d) SCIAP Ltd., Széchenyi u. 62, H-4031Debrecen, Hungary, (E-mail: halasi1@axelero.hu)

(e) BioAqua Pro Ltd., Soó R. 21, H-4032 Debrecen, Hungary, (E-mail: bkiss@bioaquapro.hu, juhaszp@bioaquapro.hu,mullerz@bioaquapro.hu,)

(f) Mátra Museum, H-3200 Gyöngyös, Hungary, (E-mail: szilagyi@vkkt.bme.hu)

(g) University of Pannonia, Department of Limnology, Egyetem u. 10, H-8200 Veszprém, Hungary, (E-mail: padisak@almos.uni-pannon.hu, stenger@almos.uni-pannon.hu)

(h) West-Transdanubian Environmental and Water Authority, Vörösmarty u. 2, H-9700 Szombathely, Hungary, (E-mail: pomogyi@freemail.hu)

(i) University of Szeged Boldogasszony sgt. 6, H-6720 Szeged, Hungary, (E-mail: szalma@jgytf.uszeged.hu)

(j) University of Debrecen, Egyetem tér 1, H-4010 Debrecen, Hungary, (E-mail: lakgyu@tigris.klte.hu,tothmerb@delfin.klte.hu)

\begin{abstract}
The classification according to Water Framework Directive (WFD) includes numerous challenges in contrast with the previously applied water qualification standards. The most important element of the ecological status, the biological one, is based on five groups of living organisms such as phytoplankton, phytobenthon, macrophytes, macro-invertebrates and fish. The results of a threeyear research project financed by the Ministry of Environment and Water (MoEW) and the Hungarian Academy of Sciences (HAS) are reported in this work. The objective of the project was the elaboration of a proposal for biological classification according to the WFD for the related groups of living organisms. In the course of the project the biological characteristics to be measured were selected for each of the above listed groups which served as the basic data for Biological Quality Elements (BQEs). In the cases BQEs we estimated the type-specific reference values for most of the Hungarian surface water types. Then, we created the structure of the qualification system for these groups, including specification of class boundaries between the five classes for the Environmental Quality Ratio (EQR) values on the basis of expert estimation. A non-taxonomic periphyton index (NTPI, not including in WFD) was also developed and tested for qualification. The elaborated classification systems were tested on the basis of existing scarce data base in the case of numerous Hungarian water types.
\end{abstract}

\section{Keywords}

Water Framework Directive, biological classification, phytoplankton, phytobenthon, periphyton, macrophytes, macro invertebrates, fish, biological indices

\section{INTRODUCTION}

The basis of the ecological quality estimation according to the WFD is the state of the five biological groups of the aquatic ecosystem (phytoplankton, periphyton forming diatoms, macrophyte vegetation, macroscopic invertebrates and fish fauna). Achievement of good ecological state or good potential could be assessed by the investigation of these biological groups while other quality 
elements are considered as supporting information (e.g., hydromorphological, or physicochemical characteristics) in determining state and potential (WFD, 2000, REFCOND, 2002, ECOSTAT, 2003). The aim of this paper is to summarize the Hungarian concept and to introduce the results so far achieved in relation to the application of WFD. The primary objective of the three year research program was to establish EQR (Environmental Quality Ratio) values for the Hungarian water types for all of the above outlined biological groups to serve as a basis of biological assessment and classification for rivers and lakes. Followed by the conceptual frame of WFD it was envisaged that qualitative and quantitative parameters have to be applied simultaneously. The final assessment was also based on the results of the ECOSURV project as well as on our own expert data and judgment (ECOSURV, 2005). Where the quality of the already available data allowed we tried to verify the function of the classification schemes by field data. Regarding the various groups of aquatic ecosystem elements this effort resulted in different levels of confidence as the quality of the available information varied widely.

\section{METHODS}

\section{Principles and Hungarian specialties}

Based on WFD and related guidelines, the Member States have to determine the reference values for each and any of the quality elements to set up the classification scheme. Determination of reference conditions is the basis of the classification. Reference status refers to the pristine (or close to natural) state which is used as reference while classifying the state of a given water body by using biological quality elements. Reference state has to be determined for all quality elements and for all of the water types. (In Hungary 22 river types [+ three for the Danube which has 3 separate types as set by the IPCDR] and according to the latest lake typology 17 lake types were separated according to the „B” typology.) The river types are described in MoEW (2005); the types of lakes have not been published yet. Human influences are allowed even in the reference state up to the point where ecological effects are very slight. Determination of the reference state can be based on: (1) measurement and assessment of reference stations; (2) by the analysis of historical data; (3) by the use of modeling; and could be based on (4) expert judgment (REFCOND, 2002, ECOSTAT, 2003).

\section{Biological parameters to be measured and classification methods}

In the course of the project we selected the biological characteristics to be measured for each of the five biological groups according to WFD which served as the basic data for Biological Quality Elements (BQEs). In the cases BQEs we estimated the type-specific reference values for the Hungarian surface water types. Then, we created the structure of the qualification system by groups of biota, including specification of class boundaries between the five classes for the Environmental Quality Ratio (EQR) values on the basis of expert estimation. Classification scheme was elaborated for all of the five biological groups including rivers and lakes.

\section{Phytoplankton}

For phytoplankton the characteristics to be measured are the species composition and species' relative contribution to total biomass and chlorophyll-a concentration of water. Species were sorted into functional groups (codons; Reynolds et al., 2002); these groups mean the reference characteristics. The qualification takes place on the basis of $Q_{k}$ index (Padisák et al., 2006) and chlorophyll-a concentration. In $Q_{k}$ index we took into account the relative abundance of the species belonging to the functional groups and the type-specific weight factor according to the newly developed functional group concept. For each type the presence of a particular codon is accepted and expected in the reference state indicating also codons that are not acceptable or neutral. For this purpose a factor value was given for each water type in the 0 to 5 interval. In conclusion we can determine a certain community index $\left(Q_{k}\right)$ : 


$$
Q_{k}=\sum_{i=1}^{s}\left(p_{i} F\right)
$$

Where $s$ is the number of species in a given sample, $p_{i}$ the relative abundance of the functional groups (codons) based on biomass and $F$ denotes the factor value between 0 and 5 of the given codon. The minimum value of the index is 0 , denoting the bad state and the maximum is 5 , indicating high quality state. The calculated value can be divided by 5 provides the EQR value in the 0 to 1 interval. Codons and weight factor of codons varies according to water types and category (river or lake). For those water types where the presence pf phytoplankton is not feasible to apply this particular group is omitted from classification. Regarding the conceptual frame on the use of codons and methodological details see publications by Padisák and Borics (in press) and Borics et al. (2007).

\section{Diatom indices and non-taxonomic index}

The samples from rivers were processed according to EN 13946 standard (own samples) and ECOSURV (2005) methods (ECOSURV samples, van Dam et al., 2005). For benthic diatoms the basis of the measured parameters are the species composition and the relative abundance of the species. The samples are collected preferably from stones. For rivers, the IPS index was used (Indice de Polluo-sensibilité Specifique; Coste and Aypassorho, 1991), calculation of which is according to Zelinka and Marvan (1961) formula, based on the relative abundance of taxa, their sensitivity to certain chemical parameters and indicator values. As the IPS uses almost all the taxa present in the sample therefore it provides more comprehensive approach with regards to taxonomic composition. This ensures better sensitivity when assessing differences amongst the ecoregions. Our analyses were based on this index. Since the available data basis was not appropriately large the limits for EQR values for good/moderate boundaries were determined by expert judgment and statistical analyses of available data. These boundaries might have to be reevaluated when sample number increases. IPS value between the excellent/good states was determined on by the median value of IPS of the reference areas (where data gap was faced then expert judgment was applied): (i) EQR for excellent/good state was determined by the 10. percentile of the median value (where data gap was faced then expert judgment was applied) by the normalization of the IPS values falling to the high category (the observed IPS/reference IPS); (2) the EQR and IPS values between the good/moderate state categories was divided to four categories below the high/good value, namely good/moderate $\mathrm{EQR}$ boundary $=\mathrm{EQR}_{\text {high } / \text { good }^{-}} \mathrm{EQR}_{\text {high } / \text { good }} / 4$, refers to good/moderate IPS boundary $=\mathrm{IPS}_{\text {high/good }}{ }^{-}$ $\mathrm{IPS}_{\text {high/good }} / 4$ (Ács and Szabó, in press).

In case of lakes the samples were collected from the surface of emergent macrophytes (the total phosphorus contents of water was taken into account as the main chemical parameter). For each species the ecological optimum of the species was calculated by regression for the investigated parameter by using the weighted average method. This was followed by a calibration step according to Stoermer and Smol (2001). Knowing the frequency of the species in the sample it is weighted by their optimum determined in prior step, then the value of the investigated environmental parameter could be estimated. Deviation from the tolerance limits were defined as the deviation by $1 \mathrm{SD}$. On the basis of the TP optimums 6 different categories were distinguished from 0 (hypertrophic) to 5 (oligotrophic). These categories were the followings: (0) > 1.500 (1) $0.401-1.500$ (2) $0.300-0.400$ (3) $0.190-0.299$ (4) 0.100-0.189 (5) $<0.090 \mathrm{mg} \mathrm{L}^{-1}$. Species were arranged to 3 categories according to their tolerance values: (1) sensitive (tolerance: $0.01-0.09 \mathrm{mg} \mathrm{L}^{-1}$ ), (2) less sensitive (tolerance: 0.1 $0.3 \mathrm{mg} \mathrm{L}^{-1}$ ) and (3) tolerant (tolerance: $0.3-3 \mathrm{mg} \mathrm{L}^{-1}$ ) species. Diatom index for the assessment of 
trophic state in lakes (TDIL) could be calculated by using the forms of Zelinka and Marvan (1961) equation. :

$$
T D I L=\frac{\sum a_{k} s_{k} v_{k}}{\sum a_{k} s_{k}}
$$

where $a$ is the relative frequency of the species $k, s$ is the sensitivity, $v$ is the value of the trophic state indicator. The value of the index varies in the 0 to 5 interval. According to the WFD requirements 5 water quality category were distinguished: bad, fair, moderate, good and high. The EQR value in the interval of $0-1$ is calculated by dividing the actual value by 5 (Stenger-Kovács et al., 2007, Stenger-Kovács and Padisák, in press).

A non-taxonomic periphyton index (NTPI) was also developed and used for qualification measuring specific weight of the periphyton, its ash and chlorophyll-a content, and index of autotrophy. The non-taxonomic periphyton index (NTPI) provides a cost-efficient rapid method of high practical relevance. The NTPI indirectly refers to the structure of the biological films and their functional state making possible its use for classification purposes. Such systems were suggested previously to use for water quality classification in Hungary and in abroad as well (Lakatos et al., 1999, Pizzaro, 1999). The suggested method is not type specific yet further data collection and processing is required for further development, but it can be used effectively beside the IPS and TDIL.

\section{Macrophyte vegetation}

Determination of the reference conditions of the macrophyte vegetation requires the measurement of the followings in case of rivers and lakes: (1) species list; (2) community composition; (3) the total plant coverage of sample area; (4) the intactness of zonation (for the whole water body). Of these measured parameters the following reference characters are calculated: (i) the zonation index (the proportion of the theoretically necessary and actually present zones); (ii) naturalness index (the weighted proportion of the abundance-dominance portion of the undisturbed/degraded state indicator species in all of the species lists). This particular index involves mass relations as well since abundance-dominance values are used for its calculation. (iii) the $\mathrm{W}$ index (index that calculated on the basis of the species list considering the abundance-dominance value of the aquatic, marshland, wetland and terrestrial vegetation, also supports to determine the boundary of the water body towards to the land); (iv) the F\% coverage index, that shows the plant coverage at low water levels. This index assist to separate the zones and concerns the whole water body; (v) the B\% coverage index indicates the portion of the plant covered and free water surface areas. This latter index refers only to the sample area. The Integrated Macrophytes Qualification Index (IMQI) is calculated using these indices with the observance of the adequate weighting on the basis of which classification happens (for more details see Pomogyi and Szalma in press).

\section{Macroscopic invertebrates}

In the case of the macro-invertebrate fauna the species composition and relative abundance were determined. Qualification then is based on an index developed for the Hungarian conditions, in which we take into account presence and absence of the type-specific type-group specific character species. Description of the reference state by types on the basis of the macroscopic invertebrates was made on the basis of the ECOSURV project data and by the use of expert judgment as well. Species were divided according to the following three types: character species, type characteristic species, and generalist species. The assessment of reference state was made according to the first two species types. Individual abundance values were calculated according to each types, and type groups. Character species occurring in abundance of below 5 ind. $\mathrm{m}^{-2}$ were classified into the first category. This means that provided that at least one individual is present in the sample the maximal character value is given to that particular sample (character value factor is 1). The other group of the character species categorized a type or group of types (average individual abundance reaches the value of 5 
ind $\mathrm{m}^{-2}$ on average). Threshold value for any species falling to this group is the average individual number in the sampling area. Should the individual abundance of the second category species reaches a given limit value the character value is multiplied by a factor of 1 , if not then the multiplying factor is 0.5 . For each character species falling to the second category an average individual abundance value is calculated (reference value), having different value for species to species. Modification factor of character species is called quantification factor. Description of the reference state is based on mass/density relations and character values. The ecological state assessment on the basis of the macroscopic invertebrates is based on the following equation by calculating the $\mathrm{Q}_{\mathrm{BAP}}$ value:

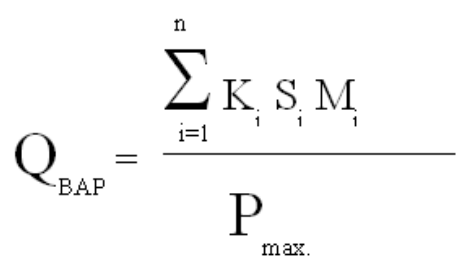

where: $\mathrm{K}=$ is the character value of each character species; $\mathrm{S}=$ the significance factor of the character species; $M=$ the quantification factor of the character species; $P_{\max }=$ the maximum potential sum of point for a given water type, calculated as the sum of the character value modified by the significance and quantification factor of the character species. The calculation of $\mathrm{Q}_{\mathrm{BAP}}$ and the $\mathrm{P}_{\max }$ value determination has to be conducted for each and any of the water type on the basis if the analysis of the sum of the points regarding the reference state of the given water type. (For more details, see: Müller, Z., Kiss, B., Juhász, P., Kovács, T., in press)

\section{Fish fauna}

The basis of the Hungarian classification scheme was the fish fauna data base of the ECOSURV (2005) project. In the first phase correspondence groups were determined by cluster analysis (by „types”, and by „type groups”; Legrende and Legrende, 1998). Following this by the application of the IndVal process we defined the character species (Dufrĕne and Legrende, 1997). Species were grouped into functional guilds according to the modified system of Karr (1991) and the classification was made according to the modified IBI (Index of Biological Integrity). For details please refer to (Halasi-Kovács and Tóthmérész, in press). We also investigated the feasibility of the use of the EFI (European Fish Index) in Hungary.

\section{RESULTS AND DISCUSSION}

Development of biological classification system in Hungary is based on multiple years research results of which are not detailed herein. Detailed tabulated forms of classification schemes by indicators groups are not presented as well we only referring the related scientific background materials. The objective of this paper was the presentation of the overall conceptual scheme and the main achievements.

\section{Determination of the type specific reference state}

The rapid ecological assessment of the reference water bodies (rivers and lakes) in Hungary was conducted in 2004 (Szilágyi et al., 2004a, 2004b). There is barely any reference location in the country that would meet WFD requirements. Research into the reference location for each and any of the water types was not successful in many cases. The determination of the reference state was also hampered by the fact that prior to 2004 no regular biological data collection corresponding to 
WFD requirements was conducted in Hungary. Regarding to the circumstances (lack of reference locations, data gaps and modeling constraints due to the missing information) the expert judgment was the only available method. Within the frame of the project we defined the reference state characteristics of the water types (the so-called passports) taking into account accessorial character parameters, such as hydromorphological, physical and chemical water quality parameters. These methods are similar to those that applied in Germany and in Austria (Borchardt, 2004). The project covered most of the aquatic groups defined in WFD (with the exception of fish and macroscopic invertebrates in lakes). The main project achievements are the following:

- It is expedient to characterize the reference state by an interval for each quality elements that reflect the reference state within a predetermined interval.

- Reference state for biological elements could be primarily defined by the character species at present. Use of abundance characteristics is largely prevented by the lack of data.

- Designation of water bodies in case of lakes was made according to the "one lake one water body" principle in Hungary. In case of spatially highly heterogeneous lakes this principle cannot be applied. The principle of relatively homogenous water body as required by the WFD cannot be met by these lakes and no single reference state could be determined for these stagnant water bodies. Improvement and refinement of typology will mitigate this problem.

- Description of reference state by macroinvertebrates and fish fauna is based on species level taxonomic determination taking into regards different character species with different weight.

- Determination of reference state in case of most of the surface water body types relies most only on expert judgment at present. Since the ECOSURV project ended in 2005, no intensive data collection is conducted regarding all of the listed biological groups covering the whole country based on unified conceptual frame. Detailed survey of the few reference sites is still missing. The type specific reference state is only defined by passports.

- Investigation of lake periphyton communities indicated that character species are largely unknown or data on them is entirely missing. The information gap should be bridged by targeted investigations. Information gap is less in case of rivers due to the results of the ECOSURV project, but in case of many types reference state is yet defined with large uncertainties. In case of lakes particularly the small ones and the dead arms, oxbows are characterized with least accuracy where not even the ECOSURV data available.

\section{Biological classification and verification}

\section{Phytoplankton}

No generally accepted method existed in Europe for the WFD adopted classification of riverine and stagnant water phytoplankton communities at the beginning of our research. Gradual development and continuous development needed for water quality classification that enables us at least potentially to achieve a robust methodology for algae based classification, even when data is missing and only the type of the water is known.. Class boundaries for certain water types were verified by phytoplankton data for those water bodies where data quality was adequate for this. In most of the cases class boundaries were determined by expert judgment. The developed method is feasible for the classification of both water categories (rivers and lakes). As far as quantitative parameters are concerned chlorophyll-a concentration might be used as supplementary parameter, but only with the method developed by us. Both quantitative and qualitative elements are incorporated to the classification scheme.

Our results indicate that the phytoplankton of the rivers is an important information carrier for the biological classification even in case when phytoplankton based assessment might not seem to be 
relevant. Presence of phytoplankton in most of our rivers is appropriate to indicate and measure anthropogenic impacts therefore its use in the classification scheme is indispensable.

\section{Diatoms indices and non-taxonomic index}

The IPS index is suggested to qualify rivers as this index takes into account most of the diatom species. The sample collection is from the stone surfaces. Based on the literature findings it is suggested that the phytoplankton composition is characteristic to human impacts and water types even in cases when the stone as substrate is not characteristic to that particular water body (such as lowland rivers). This index is particularly sensitive to pollution and human impacts and less to hydromorophological changes.

In case of lakes it is suggested to use the TDIL diatom index where samples are collected from the stems of young reed. Classification based on TDIL was verified on three large lakes in Hungary while verification was hampered in smaller lakes by the lack of data and inadequate typology. Many lakes are suggested to classify into a different category according to the TDIL, as this index is rather sensitive to pollution. In case of some special lake types (e.g., sodic lakes) nutrient levels could be high even in natural state. Trophic state of these lakes are high but not because of human impacts. This fact was taken into account when using the index. In many cases however, the lack of data prevented the classification of the lakes therefore intensive data collection is needed in future. The formerly used national typology is currently being revisited therefore the type specific classification would require further correction.

The use of non-taxonomic periphyton index as supporting information could serve as supplement for taxonomic indices for surface waters, however, this index is much too robust and non type specific. Further data gathering is needed in order to refine this index. For its advantages (simplicity, cheap and easy to communicate) it can be taken into account as a supplementary element of biological classification. Similar to this, the NTPI might be a useful supplementary tool in the classification of algal biofilms such in case of chlorophyll-a in case of phytoplankton.

\section{Macrophyte vegetation}

As for the macrophyte vegetation the use of the Integrated Macrophyte Qualification System (IMQI) as EQR based classification method is suggested to apply. This system could be applied for rivers and lakes. Its most important element is the naturalness index $\left(\mathrm{T}_{\mathrm{i}}\right)$. Other elements are the zonation index $\left(\mathrm{Z}_{\mathrm{i}}\right)$, plant coverage index $\left(\mathrm{F}_{\mathrm{N}}\right)$ and hydrophilic index (W-value). The weight of these varies depending on the type within the IMMI system. The feasibility of the IMMI was tested in the data base of the ECOSURV and it seems that the system provides adequate tool for the classification of different state water bodies. Further refinement is needed on the basis of novel data.

\section{Macroscopic invertebrates}

It is suggested to use the $\mathrm{Q}_{\mathrm{BAP}}$ index for the macroscopic invertebrate based classification in Hungary. The index takes into account the character value of the given species, its significance and quantitative relations. The index was compared on the basis of the ECOSURV results with other classification systems (AQEM, BMWP) and it turned out to be the most feasible for Hungarian conditions. The $\mathrm{Q}_{\mathrm{BAP}}$ index based classification was developed according to the WFD requirements taking into account the type specific conditions by determining the biological elements at species level along with quantitative relations. The verification of the approach was conducted for some types. Classification system, however, is not ready to use for many of the types indicating the immediate need for further developments. The macroscopic invertebrate fauna of the lakes is less known and no classification system is elaborated to this category so far. The system developed for rivers might be applied for lakes as well; however, this generalization requires further intensive data collection and assessment. 


\section{Fish fauna}

The WFD based classification system for the Hungarian rivers has been completed for fish. The EFI index seems to be inappropriate for Hungarian conditions. The basis of the national classification scheme is the index of biological integrity (IBI). This index corresponds to an EQR type number referring to the WFD required five grade scale. It is a complex indicator number that refers to the ecological attributes of the fish fauna, and compares a given site with the reference state. The prime feature of the system is that reference characters have to correlate with degradation due to human impacts and the reference state has to be free of any of the degradation symptoms due to anthropogenic effects. Class boundaries are set according to the data of the given water type on the basis of anthropogenic index classification. Determination of the EQR value is uses calculation where individual group averages are trimmed from below. In case of information gaps we used expert judgment for assessment. The classification scheme uses a bottom-up approach and verification was made for each of the water types. The verification is not fully completed yet due to missing information. No classification scheme has been elaborated for lakes till present.

\section{CONCLUSIONS}

Considering the present state of the art of the Hungarian biological classification schemes and underlying methodological background the following statements are due. Most of the suggested classification schemes in Hungary are based on international experiences and methods taking into account the specific national conditions. In some biological communities we have followed the European practice (e.g., fish), while for other groups (i.e., phytoplankton, or macrophyte vegetation) we provided further advances to European practice. For all of the five WFD based groups our aim was to establish a classification system for both rivers and lakes. In some Member State this approach is not followed, only some particular groups are representing the backbone of classification. The practice of the classification of the five groups is based on different principles due to the different ecological character of these groups. It is necessary to conduct a comprehensive national intercalibration procedure to refine class boundaries. Not all of the biological groups react in the same manner; a given anthropogenic impact has different effects on the various groups. Outliers, however, have to be corrected and reassessed. The Hungarian situation - similarly to other CEE countries - is characterized by the lack of WFD based data. The ECOSURV project eased the data gap but cannot complemented for all of the missing information. The developed systems (including the determination of the reference state) has to be further developed and refined as necessary in order to increase accuracy. Targeted investigations and completion of the classification scheme is indispensable for the biological verification of the system and improvement.

\section{REFERENCES}

Ács, É., Szabó, K. (in press). Qualification of rivers in Hungary using benthic diatoms. In: Somlyódy, L. and Simonffy, Z.: Development of sustainable water management in Hungary for the promotion of implementation of WFD. Published by Dep. of Sanitary and Environm. Eng. of BME, 2008.

Borchardt, D. (2004). Assistance in the testing of criteria for the pressure and impact analysis. Report in the frame of the Twinning Project, activity 30. Based on material provided by U. Irmer, member of the CIS-HMWB drafting group and Co-Lead of the drafting group of the good practice paper on hydromorphological issues (Manuscript).

Borics, G., Várbíró, G., Grigorszky, I., Krasznai, E., Szabó, S., and Kiss, K.T. (2007): A new evaluation technique of potamo-plankton for the assessment of the ecological status of rivers. Large Rivers Vol. 17, No. 3-4 Arch. Hydrobiol. Suppl. 161/3-4, p465-486.

Coste, M., Ayphassorho, H. (1991). Étude de la qualité des eaux du Bassin Artois-Picardie à l'aide des communautés de diatomées benthiques (Application des indices diatomiques). Raport CEMAGREF. Bordeaux-Agence de l'Eau Artois-Picardie, Douai, pp. 277. 
Dufrĕne, M., Legendre, P. (1997). Species assemblages and indicator species: the need for a flexible asymmetrical approach. Ecological Monographs 67: 345-366.

ECOSTAT (2003). Overall approach on ecological classification of ecological status and ecological potential: Final version. CIS Working Group 2/a, Report, pp. 53.

ECOSURV (2005). ECOSURV Project, Final Reports. Budapest/Arnhem, ARCADIS Euroconsult. www.euwfd.info/ecosurv.

Halasi-Kovács, B., Tóthmérész, B. (in press). Ecological classification of Hungarian rivers by fish fauna according to prescriptions of Water Framework Directive. In: Somlyódy, L. and Simonffy, Z.: Development of sustainable water management in Hungary for the promotion of implementation of WFD. Published by Dep. of Sanitary and Environm. Eng. of BME, 2008.

Karr, J.R. (1991). Biological integrity: a long-neglected aspect of water resource management. Ecological Applications 1: 66-84.

Lakatos, G., Kiss, M., Mészáros, I. (1999). Heavy metal content of common reed (Phragmites australis /Cav./Trin. ex Steudel) and its periphyton in Hungarian shallow standing waters. Hydrobiologia, 415: 47-53.

Legendre, P., Legendre, L. (1998). Numerical Ecology, 2nd English Edition. Elsevier, Amsterdam.

MoEW (2005). National Report for the European Union on the timeshared completition of the implementation of WFD in Hungary. Report of the Ministry of Environment and Water (manuscript)

Müller, Z., Kiss, B., Juhász, P., Kovács, T. (in press). Using macro-invertebrates for biological classification of surface waters in Hungary. In: Somlyódy, L. and Simonffy, Z.: Development of sustainable water management in Hungary for the promotion of implementation of WFD. Published by Dep. of Sanitary and Environm. Eng. of BME, 2008.

Padisák, J., Grigorszky, I., Borics, G., \& Soróczki-Pintér, É. (2006). Use of phytoplankton assemblages for monitoring ecological status of lakes within the Water Framework Directive: the assemblage index. Hydrobiologia 553: 114.

Padisák, J., Borics, G. (in press): Ecological classification of surface waters based on phytoplankton. In: Somlyódy, L. and Simonffy, Z.: Development of sustainable water management in Hungary for the promotion of implementation of WFD. Published by Dep. of Sanitary and Environm. Eng. of BME, 2008.

Pizzaro, H. (1999). Periphyton biomass on Echinocloa polystachya (HBK) hitch of a lake of the Lower Parana River Floodplain, Argentina. Hydrobiologia, 397: 227-239.

Pomogyi, P., Szalma, E. (in press). Integrated classification index for macrophytes (IMQI) for biological qualification of Hungarian rivers and lakes. In: Somlyódy, L. and Simonffy, Z.: Development of sustainable water management in Hungary for the promotion of implementation of WFD. Published by Dep. of Sanitary and Environm. Eng. of BME, 2008.

REFCOND (2002). Final guidance on establishing reference conditions and ecological status class boundaries for inland surface waters. Report of the CIS Working Group 2.3-REFCOND.

Reynolds, C. S., V. L., Huszar, M. Kruk, C. Naselli-Flores, L., Melo, S. (2002). Towards functional classification of freshwater phytoplankton. Journal of Plankton Research 24: 417-428.

Stenger-Kovács, Cs., Buczkó, K, Hajnal, É., Padisák, J. (2007): Epiphytic, littoral diatoms as bioindicators of shallow lake trophic status: Trophic Diatom Index for Lakes (TDIL) developed in Hungary. Hydrobiologia 589: 141154.

Stenger-Kovács, C., Padisák, J. (in press). Classification of ecological status of Hungarian lakes by epilithic diatomes. In: Somlyódy, L. and Simonffy, Z.: Development of sustainable water management in Hungary for the promotion of implementation of WFD. Published by Dep. of Sanitary and Environm. Eng. of BME, 2008.

Stoermer, E. F., Smol, J. P. (2001). The Diatoms: Application for the Environmental and Earth Sciences, Cambridge Universiy Press, UK. pp. 469

Szilágyi F., Ambrus A., Juhász P. Kovács T., Kovács Cs., Padisák J., Szalma E. (2004a). Characterization of reference sites and finalization of passports. Report of the Department of Sanitary and Environmental Engineering, BME (manuscript)

Szilágyi F., Padisák J., Szalma E. (2004b). Characterization of lake typology and its type specific reference conditions. Report of the Department of Sanitary and Environmental Engineering, BME (manuscript)

WFD (2000). Directive of the European Parliament and of the Council 2000/60/EC Establishing a framework for community action in the field of water policy. European Union, Luxembourg PE-CONS 3639/1/00 REV 1.

Van Dam, H., Padisák, J., Kovács, C. (2005). ECOSURV. BQE Report Phytobenthos. Ministry of Environment and Water, Hungary.

Zelinka, M., Marvan, P. (1961). Zur prazisierung der biologischen klassifikation des Reinheit fliessender gewasser. Arch. Hydrobiol. 57 : 389-407. 